\title{
PEMBUATAN SABUN DENGAN MENGGUNAKAN KULIT BUAH KAPUK (Ceiba petandra) SEBAGAI SUMBER ALKALI
}

\section{SOAP MAKING BY USING KAPUK FRUIT PEEL (Ceiba petandra) AS A SOURCE OF ALKALI}

\author{
Lilis Sukeksi, Andy Junianto Sidabutar, Chandra Sitorus \\ Departemen Teknik Kimia, Fakultas Teknik, Universitas Sumatera Utara, \\ Jalan Almamater, Medan, 20155, Indonesia \\ Email: andy.sidabutar94@gmail.com
}

\begin{abstract}
Abstrak
Penelitian ini bertujuan mengkaji pengaruh waktu reaksi dan suhu reaksi terhadap produk sabun yang terbentuk. Penelitian ini diawali dengan mengeringkan kulit buah kapuk dan dilakukan pembakaran untuk memperoleh abu kulit buah kapuk. Pembakaran dilakukan dengan menggunakan muffle furnace pada suhu $500{ }^{\circ} \mathrm{C}$ selama 3 jam. Kemudian dilakukan ekstraksi pada abu dengan menggunakan aquadest dengan perbandingan $1: 3$ untuk memperoleh alkali. Alkali ini direaksikan dengan minyak goreng kelapa sawit pada proses saponifikasi dengan variabel tetap volume minyak $30 \mathrm{ml}$, kecepatan pengadukan $250 \mathrm{rpm}$ dan volume minyak : volume alkali $1: 2(\mathrm{ml})$. Sedangkan untuk variabel bebasnya suhu reaksi $60^{\circ} \mathrm{C}, 70{ }^{\circ} \mathrm{C}, 80^{\circ} \mathrm{C}$, waktu pengadukan 60 menit, 90 menit, 120 menit. Respon yang diamati adalah densitas, Keasaman $(\mathrm{pH})$, bilangan penyabunan dan alkali bebas. Hasil yang terbaik diperoleh pada suhu $80{ }^{\circ} \mathrm{C}$ dan waktu pengadukan 120 menit dengan densitas $1,34 \mathrm{gr} / \mathrm{ml}, \mathrm{pH}$ 9,1, bilangan penyabunan 200,349 dan kadar alkali bebasnya $0,07 \%$.
\end{abstract}

Kata kunci: kulit buah kapuk, pembakaran, abu, saponifikasi, sabun

\begin{abstract}
The purpose of this study is to examine the effect of reaction time and temperature toward the formed of soap product. This study begins by drying the skin of cotton and burning to gain the ash of cotton fruit skin. The combustion is done by using muffle furnace at $500{ }^{\circ} \mathrm{C}$ for 3 hours. Then, extraction is done on ash by using aquadest with a ration 1:3 to obtain alkali. This alkali will be used with cooking oil from palm in saponification process with fixed volume variable oil of $30 \mathrm{ml}$, velocity of stirring is $250 \mathrm{rpm}$, and oil volume : alkali volume 1:2 ( $\mathrm{ml}$ ). Whereas for the free variable are reaction temperature at $60{ }^{\circ} \mathrm{C}, 70{ }^{\circ} \mathrm{C}, 80{ }^{\circ} \mathrm{C}$, stirring time at 60 minutes, 90 minutes, 120 minutes. The observed responses are density, acidity $(\mathrm{pH})$, saponification number and free alkali. The best results were obtained at $80{ }^{\circ} \mathrm{C}$ and stirring time of 120 minutes with a density of $1.34 \mathrm{gr} / \mathrm{ml}, \mathrm{pH} 9.1$, saponification number of 200.349 and a $0.07 \%$ free alkali content.
\end{abstract}

Keywords: cotton fruit skin, combustion, ash, saponification, soap

\section{Pendahuluan}

Tanaman Kapuk (Ceiba pentandra), adalah tanaman yang tumbuh di daerah tropis. Kapuk dibudidayakan untuk mengambil serat, sementara kulitnya cenderung dibuang. Kapuk ditemukan dalam kapsul buah matang. Pohon kapuk umumnya membutuhkan curah hujan yang melimpah selama musim berbunga dan berbuah. Buah kapuk berukuran rata-rata panjang $10-20 \mathrm{~cm}$ dengan diameter $5 \mathrm{~cm}$ [6].

Kapuk Randu banyak dijumpai di Indonesia terutama di daerah Jawa. Di Jawa Barat, perkebunan kapuk randu terbesar terdapat di daerah Lebak wangi dan Bandung, di Jawa Tengah terdapat di daerah Pati, Kudus dan Jepara, sedangkan di Jawa Timur berada di daerah Tulung Agung, Blitar, Pasuruan,dan Banyuwangi.

Kulit kapuk randu banyak mengandung Kalium dan Natrium tetapi pemanfaatannya belum maksimal. Selama ini kulit buah kapuk randu hanya digunakan sebagai kayu bakar pada industri tahu dan genteng. Di Kabupaten Pati, kulit buah kapuk randu kering diproses menjadi Soda Q dengan cara pembakaran dan ekstraksi [7]. Karena masih kurangnya pemanfaatan kulit buah kapuk maka disini peniliti mencoba menfaatkan alkali yang ada pada kulit buah kapuk sebagai sumber alkali dalam pembuatan sabun.

Sabun adalah surfaktan atau campuran surfaktan yang digunakan dengan air untuk mencuci dan membersihkan lemak (kotoran). Sabun memiliki struktur kimiawi dengan panjang rantai karbon $\mathrm{C}_{12}$ hingga $\mathrm{C}_{16}$. Sabun bersifat ampifilik, yaitu pada bagian kepalanya memiliki gugus hidrofilik (polar), sedangkan pada bagian ekornya memiliki gugus hidrofobik (non polar). Oleh sebab itu, dalam fungsinya, gugus hidrofobik akan mengikat molekul lemak dan kotoran, yang kemudian akan ditarik oleh gugus hidrofilik yang dapat larut di dalam air [6]. 
Kandungan zat-zat yang terdapat pada sabun juga bervariasi sesuai dengan sifat dan jenis sabun. Larutan alkali yang biasa digunakan pada sabun keras (sabun padat) adalah Natrium Hidroksida $(\mathrm{NaOH})$ dan alkali yang biasa digunakan pada sabun lunak (sabun cair) adalah Kalium Hidroksida (KOH) [5].

Dalam proses pembuatan sabun disini peneliti mereaksikan alkali yang ada pada kulit buah kapuk dengan minyak goreng yang bersumber dari kelapa sawit. Seperti yang kita ketahui Indonesia merupakan salah satu negara penghasil minyak sawit terbesar di dunia. Sehingga untuk memproleh minyak kelapa sawit sangat mudah dan harga yang terjangkau. Minyak dari kelapa sawit ini dapat di manfaatkan untuk pembuatan sabun, karena sabun yang dihasilkan dari minyak kelapa sawit memiliki kelebihan yaitu lebih lembut di tangan. Untuk itu peneliti menggunakan minyak kelapa sawit sebagai bahan untuk membuat sabun.

\section{Teori}

Sabun adalah garam alkali dari asam lemak dan dihasilkan menurut reaksi asam lemak. Basa alkali yang umum digunakan untuk membuat sabun adalah natrium $(\mathrm{NaOH})$ dan amonia $\left(\mathrm{NH}_{4} \mathrm{OH}\right)$ sehingga rumus molekul selalu dinyatakan sebagai RCOONa, RCOOK atau $\mathrm{RCOONH}_{4}$.

Proses pembuatan sabun dikenal dengan istilah saponifikasi. Saponifikasi adalah reaksi hidrolisis asam lemak oleh adanya basa lemah/kuat. Berikut merupakan reksi saponifikasi:

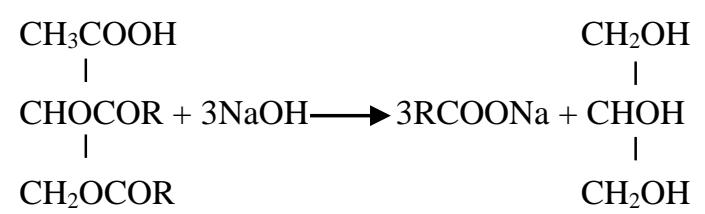

Lemak Alkali Sabun Gliserol

Sabun termasuk salah satu jenis surfaktan yang terbuat dari minyak atau lemak alami. Surfaktan mempunyai struktur bipolar, bagian kepala bersifat hidrofilik dan bagian ekor bersifat hidrofobik. Karena sifat inilah sabun mampu mengangkat kotoran (biasanya lemak) dari badan atau pakaian [6]. Lemak atau minyak yang digunakan dapat berupa lemak hewani ataupun nabati, lilin, maupun minyak ikan laut. Pada saat ini teknologi sabun telah berkembang pesat. Sabun dengan jenis dan bentuk yang bervariasi dapat diperoleh dengan mudah dipasaran seperti sabun mandi, sabun cuci baik untuk pakaian maupun untuk perkakas rumah tangga, hingga sabun yang digunakan dalam industri.

Banyaknya prosuksi sabun cair di Indonesia dapat dilihat pada tabel 1 .

Tabel 1.Produksi Sabun Cair di Indonesia Tahun 2001-2005 [2]

\begin{tabular}{|c|c|c|}
\hline Tahun & $\begin{array}{c}\text { Frekuensi } \\
(\mathrm{kg})\end{array}$ & Nilai $(\mathrm{Rp})$ \\
\hline 2001 & 415.064 & 2.324 .356 .000 \\
2002 & 883.956 & 4.950 .164 .000 \\
2003 & 989.098 & 5.322 .156 .000 \\
2004 & 1.240 .082 & 7.923 .653 .000 \\
2005 & 7.245 .937 & 29.295 .886 .000 \\
\hline
\end{tabular}

Proses pembuaatan sabun dikenal dengan istilah saponifikasi. Saponifikasi adalah reaksi hidrolisis asam lemak oleh adanya basa $(\mathrm{NaOH})$. Sabun terutama mengandung $\mathrm{C}_{12}$ dan $\mathrm{C}_{16}$ selain itu juga mengandung asam karboksilat. Saponifikasi merupakan reaksi antara asam/lemak dengan basanya yang menghasilkan sabun dan gliserol merupakan produk samping.

Faktor - factor yang mempengaruhi proses saponifikasi:

1. Suhu Operasi

Proses saponifikasi trigliserida dapat berlangsung pada suhu kamar dan prosesnya sangat cepat berlangsung.

Ditinjau dari segi termodinamikanya, kenaikan suhu akan menurunkan hasil, hal ini dapat dilihat dari persamaan Van`t Hoff :

$$
\frac{\mathrm{d} \ln K}{\mathrm{dT}}=\frac{\Delta \mathrm{H}}{\mathrm{RT}}
$$

Karena reaksi penyabunan merupakan reaksi eksotermis ( $\Delta \mathrm{H}$ negatif), maka dengan kenaikan suhu akan dapat memperkecil harga $\mathrm{K}$ (konstanta keseimbangan), tetapi jika ditinjau dari segi kinetika, kenaikan suhu akan menaikan kecepatan reaksi. Hal ini dapat dilihat dari persamaan Arhenius berikut ini:

$$
k=A e^{-E / R T}
$$

Dalam hubungan ini, $\mathrm{k}$ adalah konstanta kecepatan reaksi, A adalah faktor tumbukan, E adalah energi aktivasi (cal/gr mol), $\mathrm{T}$ adalah suhu $\left({ }^{\circ} \mathrm{K}\right)$, dan $\mathrm{R}$ adalah tetapan gas ideal (cal/gr mol.K). Berdasarkan persamaan tersebut maka dengan adanya kenaikan suhu berarti harga $\mathrm{k}$ (konstanta kecepatan reaksi) bertambah besar. Jadi pada kisaran suhu tertentu, kenaikan suhu akan mempercepat reaksi, yang artinya 
menaikkan hasil dalam waktu yang lebih cepat. Tetapi jika kenaikan suhu telah melebihi suhu optimumnya maka akan menyebabkan pengurangan hasil karena harga konstanta keseimbangan reaksi $\mathrm{K}$ akan turun yang berarti reaksi bergeser ke arah pereaksi atau dengan kata lain hasilnya akan menurun [1].

2. Pengadukan

Trigliserida, asam lemak, metil ester dan minyak sangat sukar larut dalam air, sedangkan larutan basa seperti $\mathrm{NaOH}$ sangat larut dalam air. Sehingga jika kedua reaktan ini diiamkan akan terbentuk dua lapisan dan reaksinya akan berlangsung lambat. Untuk menghindari hal tersebut maka pengadukan yang cukup kuat perlu dilakukan agar seluruh partikel dari reaktan dapat terdispersi satu sama lain dan dengan demikian laju reaksi akan semakin cepat.

3. Konsentrasi Reaktan

Dalam reaksi kimia, reaksi yang berlangsung cepat adalah pada saat awal terjadinya reaksi, karena terdapat banyak reaktan dan produk yang masih sedikit. Karena pada reaksi saponifikasi menghasilkan air sebagai produk samping yang dapat membuat laju reaksi akan semakin kecil, maka untuk menghindari hal tersebut dilakukan dengan cara melarutkan basa alkali dengan air yang secukupnya sehingga menghasilkan larutan basa yang pekat.

\section{Metodologi Penelitian \\ BahanBaku dan Peralatan}

Bahan yang digunakan dalam penelitian ini adalah kulit buah kapuk, minyak kelapa sawit, aquadest, asam klorida, indikator phenolphthalein, kalium hidroksida dan etanol

Alat yang digunakan meliputi Muffle furnace, cawan petri, neraca elektrik, beaker glass, Erlenmeyer, thermometer, oven, aluminium foil, magnetik Stirrer, gelas ukur, Stopwatch, spatula, piknometer, pipet tetes, buret, statif dan klem, $\mathrm{pH}$ meter, kertas saring.

\section{Prosedur Saponifikasi}

Proses saponifikasi diawali dengan mereaksikan minyak kelapa sawit dengan filtrate abu kulit buah kapuk diatas sebuah hot plate sesuai dengan perbandingan variable. Lalu melakukan pengadukan selama reaksi saponifikasi berlangsung sesuai dengan waktu yang ditentukan pada variable. Hasil saponifikasi yang diperoleh dipisahkan dengan menggunakan corong pemisah untuk memisahkan sabun.

\section{AnalisaDensitas Sabun}

Untuk menentukan densitas sabun ditimbang piknometer kosong dan kering dicatat massanya. Piknometer $10 \mathrm{ml}$ diisi dengan air hingga penuh. Ditimbang piknometer yang berisi dengan air dan dicatat masssanya. Selisih antara piknometer yang berisi air dan piknometer kosong adalah massa air. Dihitung volume air dengan rumus

$$
\mathrm{V}=\frac{m}{\rho}
$$

Kemudian piknometer diisi dengan sampel sebanyak volume sampel. Ditimbang volume piknometer berisi sampel dan dicatat masanya. Selisih antara piknometer berisi sampel dan piknometer kosong adalah massa sampel. Kemudian dihitung densitas sampel dengan persamaan:

$$
\rho_{\text {sampel }}=\frac{m_{\text {sampel }}}{m_{\text {air }}} \times \rho_{\text {air }}
$$

\section{Analisa Keasaman (pH)}

Disiapkan 5 gram sampel yang akan dianalisa $\mathrm{pH}$ nya. Dilarutkan sampel dalam 10 $\mathrm{ml}$ aquadest. Dicuci $\mathrm{pH}$ meter dengan aquadest dan dilakukan kalibrasi dengan larutan buffer. Dimasukkan $\mathrm{pH}$ meter ke dalam larutan sampel. Dicatat $\mathrm{pH}$ yang tampil.

\section{Analisa Bilangan Penyabunan}

Ditimbang 2 gram sampel sabun dan dicampurkan dengan $25 \mathrm{ml}$ potassium Hydroxide Etanol 0,5 mol/L. Campuran direfluks selama 30 menit. Didinginkan dan ditambahkan Phenolptalein. Dititrasi dengan $\mathrm{HCl} 0,1 \mathrm{~mol} / \mathrm{L}$ dan dicatat volume $\mathrm{HCl}$ yang terpakai. Dilakukan titrasi blangko. Dihitung bilangan penyabunan dengan rumus :

$$
\mathrm{P}=\frac{C L x(V b-V a) x T F}{W}
$$

$\mathrm{P}=$ bilangan penyabunan

$\mathrm{Vb}=$ volume titrasi blanko $(\mathrm{ml})$

$\mathrm{Va}=$ volume titrasi $(\mathrm{ml})$

$\mathrm{Cl}=$ konsentrasi konversi koefisien $(28,05)$ (potassium hydroxide ex. 56,11 x 0,5)

$\mathrm{TF}=$ faktor reagen $(1,006)$

$\mathrm{W}=$ berat $($ gram $)$

\section{Analisa Kadar Alkali Bebas}

Siapkan alkohol netral dengan mendidihkan $100 \mathrm{ml}$ alkohol, tambahkan 0,5 ml indikator Phenolphetalein. Ditimbang 5 gram sampel dan masukkan kedalam alkohol netral, pasang refluks kondensor dan didihkan selama 
30 menit. Larutan bersifat alkali (penunjuk Phenolphtalein berwarna merah). Lakukan uji alkali bebas dengan mentiternya menggunakan HCL $0,1 \mathrm{~N}$ dalam alkohol dari buret, sampai warna merah tepat hilang. Dihitung kadar alkali bebas dengan rumus:

alkali bebas $=\frac{V \times 0,056 \times N}{W} \times 100 \%$

$\mathrm{V}=$ volume $\mathrm{HCl}$ yang digunakan $(\mathrm{ml})$

$\mathrm{N}=$ normalitas $\mathrm{HCl}$ yang digunakan $(\mathrm{N})$

$\mathrm{W}=$ berat sampel (gram)

\section{Hasil Dan Pembahasan \\ Hasil Penelitian}

Karakteristik AAS alkali dari kulit buah kapuk dilakukan untuk mengidentifikasi kandungan kalium yang ada pada kulit buah kapuk. Dari hasil analisa AAS yang dilakukan diperoleh persentase kalium yang ada pada kulit buah kapuk sebesar 29,8 \% pada suhu pembakaran $500^{\circ} \mathrm{C}$ selama 3 jam.

\section{Pengaruh Suhu dan Waktu Pengadukan Terhadap Keasaman (pH) Sabun}

Berikut grafik yang menunjukkan pengaruh variasi suhu dan waktu pengadukan terhadap kadar keasaman $(\mathrm{pH})$ sabun cair yang dihasilkan:

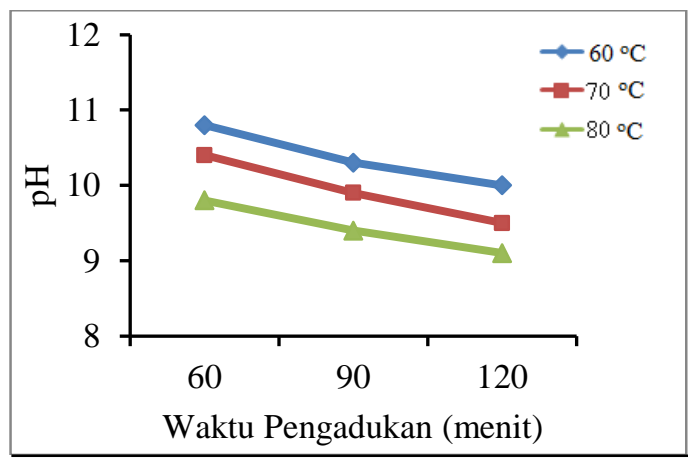

Gambar 1. Grafik Pengaruh Suhu Reaksi dan Waktu Pengadukan terhadap Kadar Keasaman Sabun Cair.

Dari gambar 1 dapat dilihat adanya pengaruh waktu pengadukan terhadap $\mathrm{pH}$ sabun yang dihasilkan. Dengan semakin bertambahnya waktu pengadukan dapat menyebabkan turunnya $\mathrm{pH}$ sabun yang dihasilkan. Sedangkan dengan semakin besarnya suhu reaksi penyabunan menyebabkan $\mathrm{pH}$ sabun menurun sampai titik optimumnya. Hal ini disebabkan oleh semakin lama waktu pengadukan menyebabkan waktu interaksi antara minyak dan alkali semakin besar, maka reaksi akan mendekati kesetimbangan sehingga residu alkali akan semakin rendah yang menyebabkan sabun tidak terlalu basa.

Berdasarkan penelitian yang dilakukan oleh Wijana, dll., 2009 [10], nilai pH memiliki kecenderungan yang semakin menurun dengan semakin lamanya pengadukan. Dan semakin besar suhu reaksi maka $\mathrm{pH}$ sabun akan semakin kecil. Tetapi jika kenaikan suhu telah melebihi suhu optimum akan menyebabkan pengurangan hasil karena harga kesetimbangan reaksi $\mathrm{K}$ akan menurun yang berarti reaksi akan bergeser ke arah pereaksi atau dengan kata lain produk akan berkurang [4][9]. Reaksi yang jauh dari kesetimbangan akan menghasilkan sabun dengan residu alkali yang besar dan berakibat pada $\mathrm{pH}$ sabun yang tinggi. Pada penelitian ini $\mathrm{pH}$ terbaik yang diperoleh adalah pada suhu 80oC dan waktu pengadukan 120 menit yaitu 9,1 . Nilai $\mathrm{pH}$ merupakan salah satu parameter hang penting dalam penentuan mutu sabun cair, karena nilai $\mathrm{pH}$ menentukan kelayakan sabun untuk digunakan sebagai sabun mandi. Sabun cair yang diperoleh pada penelitian ini memiliki $\mathrm{pH}$ antara 9,1 - 10,8 dan menurut SNI pH sabun cair berkisar antara $8-11$ [10]. Jadi sabun yang diperoleh pada penelitian telah sesuai dan layak untuk digunakan.

\section{Pengaruh Suhu dan Waktu Pengadukan Terhadap Densitas Sabun}

Berikut grafik yang menunjukkan variasi suhu dan waktu pengadukan terhadap densitas sabun cair yang dihasilkan:

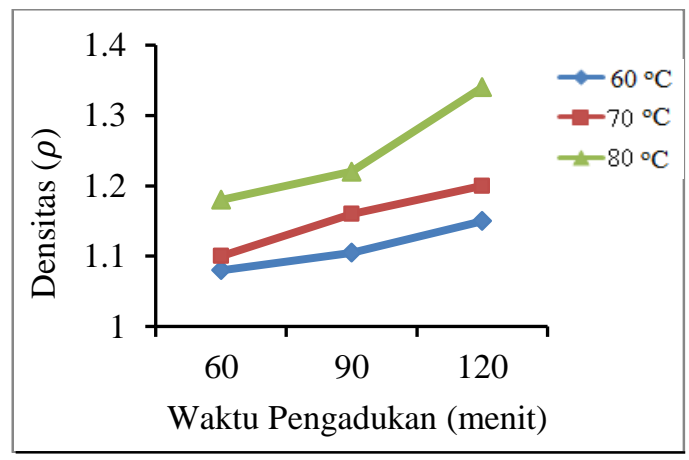

Gambar 2. Grafik Pengaruh Suhu dan Waktu Pengadukan Terhadap Densitas Sabun Cair

Dari gambar 2 di atas dapat dilihat bahwa suhu dan waktu pengadukan berpengaruh terhadap densitas sabun yang dihasilkan. Densitas sabun cenderung naik seiring dengan bertambahnya waktu pengadukan dalam reaksi penyabunan. Pengaruh suhu reaksi terhadap densitas sabun akan semakin meningkat seiring 
dengan semakin besarnya suhu reaksi penyabunan. Hal ini disebabkan oleh adanya partikel $\mathrm{H} 2 \mathrm{O}$ yang mulai menguap, yang menyebabkan kandungan air pada sabun akan berkurang sehingga sabun menjadi mengental. Penurunan viskositas akibat peningkatan rasio air/sabun dikarenakan viskositas dipengaruhi oleh kadar air dalam sabun tersebut [10].

Sabun cair yang dihasilkan pada penelitian memiliki densitas antara 1,08 - 1,34 (gr/ml) menurut SNI densitas sabun cair berkisar 1,01 1,1 (Indonesia dan Nasional 1994). Dapat dilihat bahwa ada beberapa sabun cair yang sesuai dengan Standar Nasional Indonesia yaitu pada suhu suhu $60{ }^{\circ} \mathrm{C}$ waktu pengadukan 60 menit sebesar 1,08 dan pada suhu $70{ }^{\circ} \mathrm{C}$ waktu pengadukan 60 menit sebesar $1,1(\mathrm{gr} / \mathrm{ml})$.

\section{Pengaruh Suhu dan Waktu Pengadukan Terhadap Bilangan Penyabunan Sabun}

Berikut grafik yang menunjukkan variasi suhu dan waktu pengadukan terhadap bilangan penyabunan sabun cair yang dihasilkan:

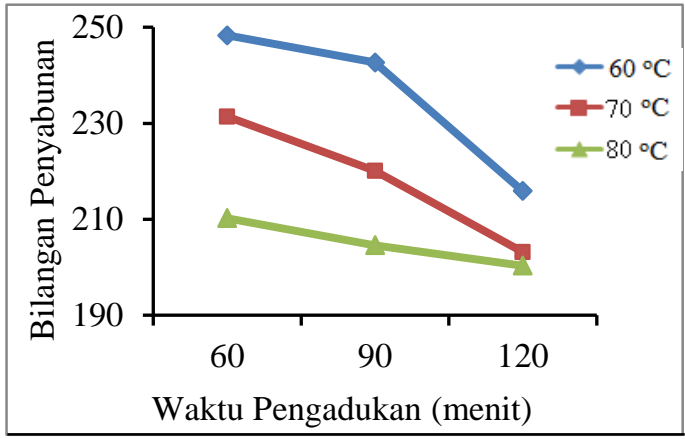

Gambar 3. Grafik Pengaruh Suhu dan Waktu Pengadukan Terhadap Kadar Bilangan Penyabunan Sabun Cair

Bilangan penyabunan adalah banyaknya alkali yang dibutuhkan untuk menyabunkan sejumlah minyak. Semakin tinggi bilangan penyabunan menunjukkan semakin tinggi pula kadar asam lemak bebas pada minyak sehingga alkali yang dibutuhkan untuk menyabunkan minyak tersebut juga akan semakin banyak [8].

Dari gambar 3 di atas dapat dilihat bahwa adanya pengaruh suhu dan waktu pengadukan terhadap nilai bilangan penyabunan. Dengan semakin bertambahnya suhu reaksi menyebabkan nilai bilangan penyabunan pada sabun akan semakin menurun. Sedangkan dengan semakin bertambahnya waktu pengadukan menyebabkan nilai bilangan penyabunan akan semakin menurun.
Hal ini disebabkan oleh semakin bertambahnya waktu pengadukan akan menyebabkan waktu reaksi antara minyak dan alkali akan semakin besar, maka reaksi akan mendekati kesetimbangan sehingga minyak yang belum bereaksi dengan alkali akan semakin kecil dan kadar asam lemak bebasnya pun semakin kecil. Dan pengaruh suhu reaksi terhadap bilangan penyabunan akan semakin turun seiring dengan semakin besarnya suhu reaksi. Pada kisaran suhu tertentu, kenaikan suhu akan mempercepat reaksi penyabunan, yang artinya menaikkan hasil dalam waktu yang lebbih cepat. Tetapi jika kenaikan suhu telah melebihi suhu optimum, akan menyebabkan pengurangan hasil karena harga kesetimbangan konstanta reaksi $\mathrm{K}$ akan turun yang berarti reaksi akan bergeser kearah pereaksi atau dengan kata lain produk akan berkurang [4]. Reaksi yang jauh dari kesetimbangan akan menghasilkan sabun dengan nilai bilangan penyabunan yang besar.

Sabun cair hasil penelitian memiliki bilangan penyabunan antara 248,231 - 200,349 dan menurut SNI nilai bilangan penyabunan adalah antara 196 - 206 (Indonesia dan Nasional 1994). Dari hasil penelitian yang sesuai dengan SNI adalah pada suhu $70{ }^{\circ} \mathrm{C}$ waktu pengadukan 120 menit dan suhu $80{ }^{\circ} \mathrm{C}$ waktu pengadukan 90 dan 120 menit yaitu berturut-turut sebesar 203,171; 204,582 dan 200,349 .

\section{Pengaruh Suhu dan Waktu Pengadukan} Terhadap Kadar Alkali Bebas Sabun

Berikut grafik yang menunjukkan variasi suhu dan waktu pengadukan terhadap kadar alkali bebas sabun cair yang dihasilkan:

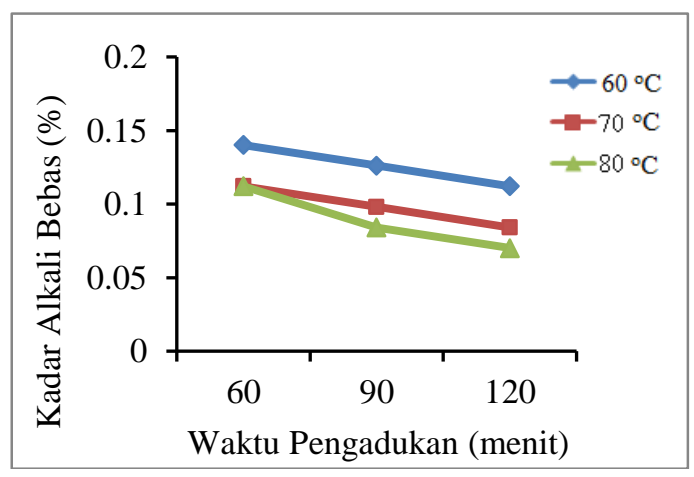

Gambar 4. Grafik Pengaruh Suhu dan Waktu Pengadukan Terhadap Kadar Alkali Bebas Sabun Cair

Dari gambar 4 di atas dapat dilihat adanya pengaruh suhu dan waktu pengadukan terhadap 
kadar alkali bebas. Dengan semakin bertambahnya waktu pengadukan dapat menyebabkan turunnya kadar kadar alkali bebaspada sabun yang dihasilkan. Sedangkan dengan semakin besarnya suhu reaksi penyabunan menyebabkan kadar alkali bebas pada sabun cair menurun sampai pada titik optimum. Hal ini disebabkan oleh semakin lamanya pengadukan maka waktu interaksi antara minyak dengan alkali akan semakin besar, maka reaksi akan mendekati kesetimbangan sehingga kadar alkali bebas pada sabun cair akan berkurang. Berdasarkan penelitian yang telah dilakukan oleh Wijana, dkk.,(2009), kadar alkali bebas memiliki kecenderungan akan semakin menurun akibat semakin besar nya suhu reaksi dan waktu pengadukan pada proses pembuatan sabun. Pada kisaran suhu tertentu.Kenaikan suhu akan mempercepat reaksi penyabunan, yang artinya menaikkan hasil dalam waktu yang lebih cepat [10]. Tetapi jika kenaikan suhu telah melebihi suhu optimum, akan menyebabkan pengurangan hasil karena harga kesetimbangan konstanta reaksi $\mathrm{K}$ akan turun yang berarti reaksi akan bergeser kearah pereaksi atau dengan kata lain produk akan berkurang [4]. Reaksi yang jauh dari kesetimbangan akan menghasilkan sabun dengan nilai bilangan penyabunan yang besar [9].

\section{Kesimpulan}

Kesimpulan yang diperoleh dari penelitian ini adalah:

1. Nilai kadar keasaman $(\mathrm{pH})$ yang terbaik pada penelitian ini diperoleh pada suhu $80^{\circ} \mathrm{C}$ dan waktu pengadukan 120 menit yaitu sebesar 9,1 .

2. Densitas sabun yang sesuai dengan SNI adalah pada suhu $60^{\circ} \mathrm{C}$ waktu pengadukan 60 menit dan suhu $70^{\circ} \mathrm{C}$ waktu pengadukan 60 menit yaitu berturu-turut sebesar 1,08 $\mathrm{gr} / \mathrm{ml}$ dan $1,10 \mathrm{gr} / \mathrm{ml}$.

3. Nilai bilangan penyabunan yang terbaik pada penelitian ini diperoleh pada suhu $80^{\circ} \mathrm{C}$ waktu pengadukan 90 menit, 120 menit dan suhu $70^{\circ} \mathrm{C}$ waktu pengadukan 120 menit yaitu berturut-turut sebesar 204,582; 200,349 dan 203,171.

4. Nilai kadar alkali bebas pada sabun yang terbaik adalah pada suhu $80^{\circ} \mathrm{C}$ waktu pengadukan 120 menit yaitu sebesar 0,07\%.

5. Ditinjau dari nilai ekonomisnya, limbah kulit buah kapuk dapat digunakan sebagai bahan baku pembuatan sabun natural.

\section{Daftar Pustaka}

[1] Astuti, Dwi Herry dan Sanny. Pemanfaatan Minyak Biji Mimba dari Biji Mimba Sebagai Bahan Pembuatan Sabun dengan Proses Semi Boiled, Seminar Nasional Teknik Kimia Soebardjo Brotoharrdjono IX, 2012,

[2] Badan Pusat Statistik, Produksi Sabun Cair di Indonesia Tahun 2001-2005, Indonesia, 2005.

[3] Badan Standarisasi Nasional Indonesia. 1994, Standar Mutu Sabun Mandi, SNI 06-3532-1994, Dewan Standar Nasional, Jakarta.

[4] Kurnia, Farid dan Ibnu Hakim, Pembuatan Sabun Cair dari Minyak Jarak dan Soda Q Sebagai Upaya Meningkatkan Nilai Paasar Soda Q, Jurusan Teknik Kimia, UNDIP, 2010.

[5] Naomi, Phatalina., M. Lumbangaol, Anna M., Toha, M. Yusuf. Pembuatan Sabun Lunak dari Minyak Goreng Bekas Ditinjau dari Kinetia Reaksi Kimia, J. Teknik Kimia, (2013) No. 2, Vol. 19.

[6] Nurhadi, S.C, Pembuatan Sabun Mandi Gel Alami dengan Bahan Aktif Mikroalga Chlorrea Pyrenoidosa Beyerinck dan Minyak Atsiri Lavandula Lativolia Chaix, Skripsi, Program Studi Teknik Industri Fakultas Sains dan Teknologi, Universitas Ma Chang, Malang, 2012.

[7] Permono, A. 2001, Pembuatan Sabun Mandi Padat, Swadaya, Jakarta.

[8] Usmania, Diah Irma Ayu and Pertiwi Widya Rahma, Pembuatan Sabun Transparan dari Minyak Kelapa Murni, Skripsi. Program Sarjana Fakultas Teknik, Universitas Sebelas Maret, Surakarta, 2012.

[9] Walter, C. Prester, B. Hoey, The Modern Soap Industry, Vol. 2, No. 2, (2000). pp. 1035.

[10] Wijana, Susinggih and T. Harnawati, Study Pembuatan Sabun Mandi Cair Dari Daur Ulang Minyak Goreng Bekas (Kajian Lama Pengadukan Dan Rasio Air : Sabun Terhadap Kualitas), J. Teknol. Peratian, Vol. 10, No. 1, 2009. 